\title{
Parks, People, and Conservation: A Review of Management Issues in Nepal's Protected Areas
}

\author{
Joel T. Heinen \\ University of Michigan \\ Bijaya Kattel \\ Colorado State University
}

\section{INTRODUCTION}

His Majesty's Government (HMG) of Nepal embarked upon a modern era of conservation with the passage of the 1973 National Parks and Wildlife Conservation Act (HMG 1977). The act allowed for the formation of the Department of National Parks and Wildlife Conservation (DNPWC), formerly an office under the Department of Forestry, and gave the newly formed department the power to create and manage four types of protected areas: national parks, wildlife reserves, strict nature reserves, and hunting reserves. The first three are recognized by the International Union for the

Please address correspondence to Joel Heinen, School of Natural Resources, University of Michigan, Ann Arbor, MI 48109-1115

We thank Mr. B.N. Upreti, Director General of the DNPWC, for his encouragement and approval of our work in several parks and reserves of Nepal, and USAID and WWF-US for financing our various research projects related to wildlife conservation and reserve management over several years. We would also like to thank the many DNPWC field officers for facilitating our various trips to Nepal's reserves, and for providing much useful information. The first author would like to thank former Deans Rajbandari and Prajapati of the Institute of Forestry, Pokhara Campus, and its faculty, staff, and diploma students, for providing transportation, library use, housing, research leave, accompaniment in the field, and stimulating conversations about $\mathrm{Nepal}$ and its natural resources on many occasions during his three years as lecturer in the Wildlife Conservation Program. 
POPULATION AND ENVIRONMENT

Conservation of Nature and Natural Resources (IUCN), now the World Conservation Union, as Protected Area Categories II (national parks), IV (wildlife reserve), and I (strict nature reserve), respectively (IUCN, 1986; 1990). While the fourth type of protected area recognized in Nepalese law does not correspond precisely with any IUCN category, it is most similar to Category VIII (multiple use management areas) in the IUCN listing as managed in Nepal. A later amendment gave HMG the power to recognize a fifth type of protected area in response to a newer proposal (Sherpa et al, 1986). This type, a conservation area, approximately corresponds to IUCN Category V (managed landscape).

Since the passage of the this landmark act, HMG has created seven national parks, four wildlife reserves, one hunting reserve, and one conservation area (Table 1). An additional protected area is soon to be created, and several other reserves of various kinds have been proposed, but were not created for various reasons. To date approximately $10 \%$ of the land area of Nepal is under some form of protection. Conservation in general has been a high priority of HMG, and several bi- and multilateral organizations were instrumental in the development of this sector in the country. The United Nations Development Program (UNDP), in conjunction with the Food and Agriculture Organization of the United Nations (FAO) were prime among them (UNDP, 1973; 1980). The King Mahendra Trust for Nature Conservation (KMTNC), a non-governmental organization, was created to promote, finance, and coordinate conservation projects throughout the Kingdom (HMG, 1982). Nepal has also planned a National Conservation Strategy with aid from the World Conservation Union (IUCN, 1984a and b).

The rapid development of conservation programs in Nepal was at least partly due to the litany of environmental problems in the country (e.g. Eckholm, 1976; Carson, 1985). Despite the relatively rapid development in conservation activities, governmental support, and the legal protection granted to many natural areas in the country, there is human encroachment and many management problems in all of Nepal's protected areas, some of which are rather severe. The purpose of this paper is to review the protected area system of Nepal and point out the legal and managerial successes and failures of these reserves on a case by case basis. We also discuss some topics and programs which affect Nepalese reserves in general, especially those related to human management issues. We have relied on published accounts where available, as well as unpublished DNPWC and other documents and interviews with wardens and former wardens where published accounts were not available. 
JOEL T. HEINEN AND BIJAYA KATTEL

\section{TABLE 1}

The national parks and reserves of Nepal

\begin{tabular}{llcc}
\hline Name & \multicolumn{1}{c}{ Location } & $\begin{array}{c}\text { Size } \\
(\mathrm{sq} \mathrm{km})\end{array}$ & $\begin{array}{c}\text { Date of } \\
\text { Establishment }\end{array}$ \\
\hline Kosi Tappu WR & Eastern Terai & 175 & 1976 \\
Parsa WR & Central Terai & 500 & 1984 \\
Royal Chitwan NP & Central Terai & 932 & 1973 \\
Royal Bardia NP & Mid-west Terai & 968 & 1976 \\
Sukla Phanta WR & Far-west Terai & 155 & 1976 \\
Shivapuri WR & Kathmandu Valley & 114 & 1985 \\
Khaptad NP & Far-west Hills & 225 & 1985 \\
Makalu-Barun & Eastern Himalaya & 2,330 & 1991 \\
Sagarmatha NP (Mt. Everest) & Eastern Himalaya & 1148 & 1976 \\
Langtang NP & Central Himalaya & 1710 & 1976 \\
Annapurna CA & Western Himalaya & 3400 & 1988 \\
Dhor Patan HR & Mid-west Himalaya & 1325 & 1984 \\
Rara NP & Mid-west Himalaya & 106 & 1976 \\
Shey Phoksundo NP (Dolpa) & Mid-west Himalaya & 3555 & 1984 \\
& \multicolumn{1}{c}{ Total Area: } & $16,643 \mathrm{sq} \mathrm{km}$ & \\
\hline
\end{tabular}

The abbreviations used are Wildlife Reserve (WR), National Park (NP), Hunting Reserve (HR), and Conservation Area (CA).

\section{GEOGRAPHIC BACKGROUND}

Nepal is renowned for its natural beauty and biological, geographic and cultural diversity. Elevations range from $75 \mathrm{~m}$ above sea level in the eastern lowlands to the highest peaks on earth, in a 147,181 sq km land area. For the sake of simplicity, the country can be divided into regions with certain physiographic traits. The regions are:

1. The Terai and Inner Terai are characterized by a subtropical climate and were originally largely dominated by sal (Shorea robusta) forests with sisoo (Dalbergia sissoo) and silk cotton (Bombax ceiba) found in river plains. The region includes elevation up to about $450 \mathrm{~m}$ although some parts of the discontinuous Siwalik Range, the first folds of the Himalayas which separate the Terai and Inner Terai, are over $600 \mathrm{~m}$ in elevation and are dominated by pine (Pinus sp). The Terai extends across Nepal's $900 \mathrm{~km}$ southern border with India, and is the northernmost extension of the Gang- 
POPULATION AND ENVIRONMENT

etic Plain. It covers about $17 \%$ of the land area of Nepal. The region has undergone substantial forest clearing in the past two decades.

2. The middle hills, north of the Terai, range from $450 \mathrm{~m}$ to $3650 \mathrm{~m}$ (the tree line) in elevation. This includes about $60 \%$ of the land area of Nepal, and a great deal of biotic diversity brought about by altitudinal change. Lower slopes are dominated by subtropical sal forests, while temperate and cold temperate forests of spruce (Picea sp) and fir (Abies sp) occur near the tree line. A host of broad-leaf species such as oak (Quercus $\mathrm{sp}$ ) and Rhododendron occur along this altitudinal gradient. Permanent settlements are found up to about $3650 \mathrm{~m}$, and elevations up to about $1800 \mathrm{~m}$ are rather densely populated. The region is characterized by substantial forest clearing and over-grazing, reflecting those historic population trends.

3. The Himalaya and trans-Himalaya, for our purposes, are those areas above the $3650 \mathrm{~m}$ tree line. The area up to the snow line (ca. $4900 \mathrm{~m}$ ) is dominated by low scrub such as juniperus, and alpine meadow. The trans-Himalaya includes that region north of the main Himalaya and is characterized by cold, high elevation deserts typical of the Tibetan Plateau. In Nepal, such areas are found along the north-central and northwestern border with Tibet; the northeastern border is formed by the peaks themselves.

The physiographic characteristics of these regions are discussed in more detail in Stainton (1972), Majapuria (1981; 1984), and Joshi (1986). Tree species characteristic of each region are discussed by Storrs and Storrs (1984), the avifauna is discussed by Fleming et al (1984) and Inskipp and Inskipp (1985), and wildlife is discussed by Shrestha (1981). General population and land use information is provided by HMG (1987a, 1991).

\section{THE PROTECTED AREAS OF NEPAL}

Some information about tourism into Nepal's existing protected areas is provided under subheadings for each area. Additional information is provided by Bezruchka (1985) and HMG (1987b). The DNPWC has published brochures with visitor information for all parks and several reserves. The dates of establishment given for each protected area are the dates that the boundaries were published in the Nepal Gazette; in some cases, this was one or several years after the reserve was created and staffed. We present Nepal's protected areas on a region by region basis, beginning with the Terai. 
JOEL T. HEINEN AND BIJAYA KATTEL

\title{
PROTECTED AREAS IN THE NEPALESE TERAI, EAST TO WEST
}

\author{
Kosi Tappu Wildlife Reserve
}

Kosi Tappu was established in 1976 and is approximately 175 sq $\mathrm{km}$ in area. It was designated a Wetland of International Importance in 1987 (IUCN 1990). The entire reserve is located within the floodplain of the Sapt Kosi River, a major tributary of the Ganges, and is subject to extensive seasonal floods during the summer monsoon. Kosi Tappu is the only Nepalese reserve with a population of wild buffalo (Bubalus bubalis), the highly endangered wild progenitor of domestic water buffalo. The headquarters is located in Kusaha, Sunsari District, in southeastern Nepal. A modest lodge for tourists is operated by reserve staff. The reserve has easy access by road from Kathmandu or Biratnagar.

The wild buffalo of Kosi Tappu were studied by Dahmer (1978) and Heinen (in press a). Within this ten-year time interval, the population rose from an estimated 63 to 93 individuals for an average growth rate of $3 \%$ per year. Other large terrestrial mammals found in Kosi Tappu include spotted deer (Axis axis), hog deer (Axis porcinus), blue bull (Boselaphus tragocamelus), and wild boar (Sus scrofa). A small population of Gangetic dolphin (Platanista gangetica) is found in the Kosi River, and individuals are seen in the reserve on occasion. Otters (Lutra sp.), fishing cats (Felis viverrina), jungle cats ( $F$. chaus), and several species of civets have also been recorded, as well as over 300 species of birds (Inskipp 1989). The Kosi Barrage area south of the reserve is well known for winter concentrations of migratory waterfowl, and several species of birds have been recorded there and nowhere else in the country (inskipp \& Inskipp, 1985). Gharial crocodiles (Gavialis gangeticus) from a captive rearing program in Chitwan National Park (see below) were released in Kosi Tappu in 1982 and 1984, but a 1987 survey indicated that very few of these animals have stayed in the reserve (Heinen 1987). The DNPWC maintains eight domestic elephants (Elephus maximus) at the reserve headquarters, and Kosi Tappu has the distinction of being the only reserve in Nepal which has successfully and repeatedly bred elephants. Seven calves have been born on the reserve as of 1990 (Dhungel et al, 1990).

Management problems in this reserve include illegal grazing by domestic livestock and some illegal wood and fodder cutting (Heinen in press b). The grazing problem is especially acute; as of 1988, an estimated 7,000 head of livestock lived on the reserve, including over 100 domestic buffalo, which readily breed with wild males. This practice is encouraged by buffalo owners as they believe that it improves vigor in the calves. 
POPULATION AND ENVIRONMENT

Wildlife mortality from monsoon floods is another problem in Kosi Tappu, but is virtually impossible to control. The area surrounding the reserve is densely populated up to the boundaries. Many animals which escape the floods when the whole reserve is inundated are killed by local villagers if found in cultivated fields. Extending the reserve may help to alleviate these problems.

The attitudes of local residents regarding the reserve are generally poor despite that an estimated US $\$ 250,000$ worth of thatch was removed during the 1987 thatch cutting season. Reserve staff also supply permits to collect fish, edible fruits and ferns, and Bombax ceiba seeds used to stuff pillows. Attitudes and interactions of the reserve with local people were studied by Heinen (in press b).

\section{Parsa Wildlife Reserve}

Parsa was created in 1984 and is $500 \mathrm{sq} \mathrm{km}$ in area. The reserve is essentially an eastern extension of Chitwan National Park (see below), and as such it represents important additional habitat for many species found in Chitwan. The headquarters is located in Adhabar, Parsa District, and has regular bus service from Pokhara and Kathmandu. There is currently no special facilities for tourists in Parsa.

The eastern portion of the reserve is characterized by very sandy soils and a low water table with no permanent water sources. A small wild elephant herd, estimated at 12 to 15 animals, is apparently resident in Parsa, and breeding has been reported. Tigers (Panthera tigris) are regularly reported in the reserve, and rhinos (Rhinceros unicornis) are occasionally found along the Rapti River that forms the northern boundary. No comprehensive wildlife surveys have been carried out in Parsa to date. The area should support many of the same species found in Chitwan, but the lack of permanent water on the eastern side may limit populations in some large ungulates.

Four smali villages are located within the reserve. The main management problem reported in Parsa is illegal timber cutting; good quality sal forest covers most of the area, and it is suspected that much the illegally harvested timber is transported across the Indo-Nepalese border and sold in Bihar, India (T.R. Dhakel, personal communication, former warden, Parsa Wildlife Reserve). Only two small army guard posts were formerly located along the $30 \mathrm{~km}$ access road which demarcates Parsa's southern boundary, making law enforcement very difficult. Additional army staff has since been posted in the reserve. Some illegal livestock grazing is also reported. 


\section{Chitwan National Park}

Chitwan is the most visited national park in Nepal and is the major tourist attraction in the Terai of the country, with over 25,000 visitor entries recorded annually in recent years (R.P. Yadhav, personal communication, warden, Chitwan National Park). The park was established in 1973 with the passage of the NPWCA, and was increased to its present size of $932 \mathrm{sq} \mathrm{km}$ in 1978. The headquarters is located in Kasara and the main tourist location is Sauraha, both located in Chitwan district. Sauraha is a $6 \mathrm{~km}$ walk from Tadi Bazaar, and can be reached from Kathmandu or Pokhara by bus. Chitwan was declared a World Heritage Natural Site in 1984 because it contains habitat for many endangered species and has an extremely high animal biomass (Thorsell, 1985). Endangered species found in Chitwan include rhino, tiger, elephant (occasional), gaur (Bos gaurus), leopard cat ( $F$. bengalensis), dolphin (few), gharial, python (Python morulus), and several species each of hornbills, storks and floricans (Bolton, 1975; Majapuria, 1981; Shrestha, 1981). Over 450 species of birds have been recorded in Chitwan (Inskipp, 1989).

Chitwan also has the distinction of being the most researched park in Nepal, and possibly in all of Asia. Studies have been carried out on tigers (Tamang, 1979; McDougal, 1980; Smith, 1980), prey species of tigers (Mishra, 1981; 1982; Dhungel, 1985), rhinos (Laurie, 1978; Dinerstein \& McCracken, 1990), gharial (Maskey, 1982; 1984), fish (Evans et al. 1985; Edds, 1988), birds (Halliday, 1982), crop depredation by wildlife (Milton \& Binney, 1980), and human uses of grasslands (Lehmkuhl et al, 1988). On-going research is focussing more on the human dimensions to park management in Chitwan, sponsored by the King Mahendra Trust for Nature Conservation. Given all the research and protection afforded to Chitwan, as well as its special status as a World Heritage Site, it is not surprising that populations of many species have increased in the park. Rhinos, for example, have gone from an all-time low of less than 100 animals to their current population of over 350 (Dinerstein \& McCracken, 1990). The tiger population has risen from about 25 individuals to about 70; the ungulate biomass has risen dramatically.

Concomitant with this increase in animal populations, the human population growth rate of Chitwan District has been ca. 3.5\% per year, far higher than that of Nepal as a whole $(2.7 \%$; HMG, 1991); this has led to the great park/people management problems discussed by Mishra (1984). People living around the park regularly suffer from crop damage and predation on livestock by wildlife, and villagers are killed on occasion by rhinos and tigers. The main product that the park provides people is thatch during the annual cutting season, but there is currently no system to com- 
POPULATION AND ENVIRONMENT

pensate villagers for damage they incur by wildlife (Upreti, 1985). Unlike the situation in Sagarmatha (see below), relatively few local residents benefit from the tourism industry in Chitwan. Most tourism is concentrated in a small area around Sauraha, and many individuals owning lodges are not native to the region. Some employment opportunities are provided to local people, but these are generally as low-paying jobs such as kitchen help and jungle guides. Several projects have addressed some of these problems; Heinen (1990) described the design of a training program for tour guides to improve skills and increase employment opportunities, and Heinen and Thapa (1988) conducted a study on the feasibility of a trekking trail which would spread tourist impacts, both positive and negative, over a larger area.

There are currently many options available in Chitwan to accommodate tourists of various means ranging from Tiger Tops, which is located inside the park and features tiger and leopard baiting, to many small private lodges in Sauraha, outside the boundaries (US $\$ 2.00$ per day, all else extra). Five private lodges are now located inside the park. They are required by law to pay an annual fee to HMG in exchange for operating privileges as stipulated in the 1973 act. All five, as well as many small lodges located outside the park, maintain offices in Kathmandu from which excursions can be booked. Several other private companies are applying for operating privileges inside Chitwan. Tourists staying in lodges outside the park are required to pay the daily admission fee of NRs 200. Guided jungle walks and drives can be arranged through many of these private lodges, and boat and elephant rides can be arranged at the ticket office in Sauraha. A visitor's center is also located in Sauraha, and a small museum is located at the park headquarters in Kasara.

Other special features of the park include an Elephant Breeding Center at Korsor, near Sauraha (Dhungel et al, 1990), an important program because of the precarious state of the Asian elephant in the wild (Santiapillai and Jackson 1990). The gharial rearing project located in Kasara was begun in 1978 with financial assistance from the Frankfurt Zoological Society. The project's activities include collecting eggs from wild gharial nests and rearing the young until they are about $1.5 \mathrm{~m}$ in length, at which time they are released into the wild. To date, several hundred gharial have been released into rivers in Nepal. Similar projects are underway in India (e.g. Bustard, 1982) and are very important because of the extremely precarious status of the gharial; by 1972, it was estimated that there were only 200 wild individuals left, and the largest single population was that found in Nepal (about 50 adults).

Because the rhino population has increased in Chitwan, the DNPWC 
JOEL T. HEINEN AND BIJAYA KATTEL

and KMTNC have sponsored a program to reintroduce the species into Bardia National Park beginning in 1986 and continuing to the present (Dinerstein \& McCracken, 1990); early results are encouraging. India is also attempting to reintroduce the species into Dudwa National Park, located south of Bardia. Some of the animals released in Dudwa came from Chitwan, in exchange for 16 domestic elephants which became the core of Nepal's Elephant Breeding Center.

Chitwan is bordered by Parsa in the east and Valmiki Wildlife Reserve in the Indian state of Bihar to the south, for a total contiguous area of about $1,900 \mathrm{sq} \mathrm{km}$. This entire area is one of the largest effective protective areas in the lowlands of the Indian Subcontinent; as such it is very important for international conservation. The only other lowland protected area in the region approaching this size is the Sunderbans in Bangladesh and India (IUCN, 1990).

\section{Bardia National Park}

Bardia, formerly called Karnali, was created as a wildlife reserve in 1976, and was increased to its present size of $968 \mathrm{sq} \mathrm{km}$ in 1983, making it the largest single protected area in the Nepalese Terai. It was upgraded to national park status in 1989. Bardia rivals Chitwan in its abundance and diversity of wildlife, but it is comparatively poorly studied. Bolton (1976a) did preliminary wildlife surveys in the area, and Dinerstein (1979a and b; 1980) studied the plant communities and ungulate biomass. Bolton (1976a) recognized the importance of the reserve, and was the first to suggest making it into a national park; however, due to the lack of a paved road in that part of the country, the area is comparatively difficult to reach, and the potential for tourism is low. Tiger Tops maintains a small tented camp under license by HMG.

Special features of Bardia include a small population of the endangered swamp deer (Cervus duvauceli), black buck (Antilope cervicapra), gharial, and wild elephants. Gangetic dolphin are regularly reported in the Karnali River which forms the western boundary of the reserve. Bauer (1990) did the most recent census on swamp deer; the population numbers about 50 animals and the blackbuck number less than 20 individuals. The latter were captive-bred animals that were released from the national zoo in Jawalakhel, Kathmandu. A much larger population of wild black buck (ca. 200 animals) is found in Guleria, south of the park.

Residents of the area are in favor of selling their land to the DNPWC due to the rapid increase in the population of these antelopes, and the crop destruction that has resulted. Plans are underway to create a blackbuck reserve in Guleria. 
The small population of gharial found in the Karnali River supplies eggs for a rearing project patterned after that in Chitwan; although hatching success of eggs has been high, there has been almost $100 \%$ mortality of juveniles at this project. The reasons for this are unknown and are causes of concern as the other crocodile-rearing projects in India and Nepal have all had high success rates. It is interesting to note that the Government of India maintains a similar facility on the IndoNepalese border in Katerniaghat Wildlife Reserve downstream from Bardia, and reported successful results (Bustard, 1982).

A small herd of wild elephants is occasionally reported in Bardia, but it is thought that these animals use a much larger area which may extend into Katerniaghat, located ca $15 \mathrm{~km}$ to the south. Rhinos from Chitwan have been released into Bardia beginning in 1986, but it will take several years to assess the effectiveness of the program. Bardia also has large populations of more common ungulates such as four species of deer, bluebull and wild boar, as well as populations of large carnivores such as tiger, leopard (Panthera pardus), and sloth bear (Melursus ursinus). As the number of tourists increases to Chitwan, it may be desirable to expand tourism into Bardia, thereby alleviating some pressure from Chitwan. Although comparatively little information is available, it appears that the habitat structure and biological diversity of Bardia approach those of Chitwan, and these qualities are the reasons that Chitwan was made into a World Heritage Site. Expanding tourism in Bardia may be possible once the highway is paved in the district.

The park/people conflict described for Chitwan is much less severe in Bardia, largely because the district is less populated and a lot of forest area remains outside the park, offering a buffer.

\section{Sukla Phanta Wildlife Reserve}

Sukla Phanta is located in the Terai of the Far Western Development Region; the headquarters is in Mahendranagar, Kanchanpur District, which can be reached by local bus from Dhangadhi Airport. The reserve is $155 \mathrm{sq} \mathrm{km}$ in area, and there is a proposal to increase its size by an additional $100 \mathrm{sq} \mathrm{km}$. A private lodge for tourists has recently begun operations in Sukla Phanta.

Special features of Sukla Phanta include Nepal's largest population of swamp deer (about 1,500) and wild elephants (about 30), including one individual thought to be the largest living Asian elephant (Byrne 1990). Hispid hare (Caprolagus hispidus) were recently rediscovered in Sukla Phanta, and several species of endangered birds such as Bengal florican (Houbaropsis bengalensis) have been recorded. A small population of tigers is resident in the reserve. Sukla Phanta is located within ca. 
$15 \mathrm{~km}$ of Dudwa National Park, and this proximity along with the large areas of district forest around the reserve may be important for maintaining large mammal populations in the reserve. Despite Sukla Phanta's comparatively small size, other large carnivores such as leopard, sloth bear and hyena (Hyaena hyaena) have been recorded in the reserve. The abundances of common ungulates such as spotted deer, wild boar, and hog deer are also high.

Management problems in Sukla Phanta include some poaching although this is probably negligible.

There is sufficient forest area outside the reserve which offers an effective buffer. Some livestock grazing occurs in the reserve, but it is not nearly as severe as that described for Kosi Tappu or Chitwan. Like Bardia, Sukla Phanta is poorly studied. A project on the Hispid hare concluded that the annual cutting and burning of grasslands is detrimental to the species (Bell 1987). Swamp deer were studied by Schaaf (1978), but the population is thought to be increasing and is greatly in need of further study. The large grassland or "phanta" from which the area's name was derived may represent potential habitat for black buck and pygmy hog. Much more research is need in Sukla Phanta.

\section{PROTECTED AREAS IN THE MIDDLE HILLS OF NEPAL, EAST TO WEST}

The Middle Hills contain the majority of Nepal's land area, yet only two small protected areas are located entirely within them. These are described here, but it should also be pointed out that all of the Himalayan parks (next section) contain some area below the tree line and therefore afford some protection to flora and fauna associated with the Middle Hills.

\section{Shivapuri Wildlife Reserve}

Shivapuri is $114 \mathrm{sq} \mathrm{km}$ in area and is located along the northern rim of Kathmandu Valley. It was managed by the Department of Soil Conservation until 1990.

Various watershed projects had been underway in Shivapuri since 1976 because the area supplies the bulk of the drinking water for Kathmandu Valley; the last of these projects began in 1985 and lasted until 1990 with financial assistance from the Government of Norway (Carter, 
POPULATION AND ENVIRONMENT

1987). The area was declared a wildlife reserve at the beginning of that project, but management did not change to DNPWC until the end. Due to the history of deforestation and overgrazing in the area, there was concern that the quality of the city's water supply was in jeopardy; since the creation of Shivapuri, firewood collection and grazing have been controlled, and forests are regenerating.

Wildlife recorded in the area include leopard, wild boar, barking deer (Muntiacus muntjak), and many species of birds. Avian diversity and abundance should increase further as the forests continue to regenerate.

A monastery is located within Shivapuri, and due to the reserve's proximity to Nepal's largest population center, it has great potential for attracting both foreign and national visitors, especially for the purposes of conservation education. A visitor's center aimed at Nepali nationals would be a great asset in the reserve because it is possible for school groups of all ages to visit the area on a daily basis from any part of Kathmandu Valley.

\section{Khaptad National Park}

Khaptad is located in the Middle Hills of the Far Western Development Region and was established in 1985. The park is $225 \mathrm{sq} \mathrm{km}$ in area and the headquarters is located on Khaptad Lekh at an elevation of about $3050 \mathrm{~m}$. Most of the park is located on the lekh: a rolling plateau of grassland mixed with coniferous and broad-leaved forest. Side slopes around the lekh and within the park descend to elevations of about $1850 \mathrm{~m}$. There are very few foreign tourists visiting Khaptad, as it is rather difficult to reach. Air service to STOL strips in the region is not always reliable, and there are currently no tourist facilities. The ticket office is located in Jingrana.

The most important special feature of Khaptad is the Ashram of the Khaptad Baba or Swami, considered to be a Hindu Saint. The Baba has lived in the area for over 40 years, and devout masses of Hindu pilgrims visit the park every year. The park was created at the Baba's suggestion, and the forests of the region are protected in large part by religious devotion to the area. A small sacred lake is also located within Khaptad.

Wildlife recorded in Khaptad include leopard, Himalayan black bear (Selenarctos thibetanus), wild dog (Cuon alpinus), wild boar, musk deer (Moschus moschiferus), goral (Nemorhaedus goral), Himalayan tahr (Hemitragus jemlahicus), as well as a host of bird species. Many local people from the area graze livestock on Khaptad Lekh; this practice has not been studied, and there are plans to restrict it. 
JOEL T. HEINEN AND BIJAYA KATTEL

This is the main management problem reported in Khaptad because its religious significance effectively protects it from other forms of encroachment such as poaching or wood cutting. Many medicinal herbs are found in the park, and an herb farm was formerly located on Khaptad Lekh.

\section{PROTECTED AREAS IN THE HIMALAYAS AND TRANS- HIMALAYAS OF NEPAL, EAST TO WEST}

\section{Makalu-Barun National Park/Conservation Area}

The 400sq km Barun Valley, located east of Sagarmatha National Park, is a biologically very important area. It is uninhabited, and is one of the only unexploited regions in the mountains of Nepal. A recent wildlife survey listed 131 species of birds including two new to Nepal and one which has not been recorded in the country since 1846. Fourteen other rare species of birds were recorded in the survey, as were 25 species of mammals. Among the latter were five protected species: Assamese monkey (Macaca assamensis), red panda (Ailurus fulgens), musk deer, great Tibetan sheep (Ovis ammon hodgsoni), and snow leopard. The report (Taylor-Ide 1985) proposed complete protection for the area, and the region was then proposed as a national park (Taylor-Ide \& Shrestha, 1985). A seminar on the region was also held that year (Anonymous, 1985). The Barun Valley contains some of the last remaining cloud forests in Nepal.

A more recent proposal (Mali \& Shah, 1987) called for a 1,380 sq $\mathrm{km}$ area to become an eastern extension of Sagarmatha National Park. The area will be divided into 11 different zones in three categories: traditional areas (in which grazing and fuel wood collection are permitted), rehabilitation areas (which allow restricted use), and core areas/ strict nature reserve which will include all of the Barun Valley. The entire area will include the Barun, Hinku, Hongu, and Mangrawa Valleys, and many major Himalayan peaks including Makalu, the world's fifth highest mountain. The extension will protect regions ranging from subtropical forests to cold, high altitude deserts. The Hongu Valley was surveyed by Jackson and Ahlborn (1986), and extended surveys in both the Hinku and Hongu have been completed. Sherpa, Rai, and Gurung ethnic groups are found in this sparsely-inhibited region; the juncture of the Barun and Arun Rivers is considered sacred by Hindus and is a popular pilgrimage site in Autumn. The 1987 proposal called for a rural development scheme to improve the economic conditions of local residents.

The most recent proposal calls for the creation of an integrated $\mathrm{Na}$ tional Park and Conservation Area separate from Sagarmatha National 
POPULATION AND ENVIRONMENT

Park, in part because of the difficulty of managing the entire area from Sagarmatha's headquarters. This proposal calls for similar zoning criteria described above, but the area will be much larger: $2,330 \mathrm{sq} \mathrm{km}$, of which 1,500 will be national park and 830 will be conservation area (Anonymous 1990). This plan is part of the Heart of the Himalayas Conservation Program, sponsored by the Woodlands Mountain Institute in conjunction with the Government of China and HMG, Nepal. The Chinese have recently establish Oomolangma Nature Preserve, approximately $10,000 \mathrm{sq} \mathrm{km}$ in area, adjacent to both Sagarmatha and Langtang National Parks, in the Tibetan Autonomous Region. The total contiguous protected land area within the region (including MakaluBarun) is thus more than $15,000 \mathrm{sq} \mathrm{km}$. Legislation to designate MakaluBarun is still pending.

\section{Sagarmatha (Mt. Everest) National Park}

Sagarmatha is the most visited mountain park in Nepal, with over 10,000 foreign visitors reported in recent years (HMG, 1987b). The park was proposed in 1971 (Blower, 1971), established in 1976, and was declared a World Heritage Natural Site in 1980 (IUCN, 1990). The headquarters is located in Namche Bazaar at an elevation of $3500 \mathrm{~m}$. in Solu Khumbu District, a one-day walk from the STOL airstrip at Lukla. The park is $1148 \mathrm{sq} \mathrm{km}$ in area, but the proposed Makalu-Barun extension will greatly increase the land area. The ticket office is located in Jorsale, a four-hour walk from Lukla.

Sagarmatha is home to about 2,500 people, mostly Sherpa, a group of Tibetan origin that is thought to have migrated to Nepal about 500 years ago. They existed for centuries as pastoralists, long distance traders, and agriculturists. The trade routes were closed after the Chinese invasion of Tibet, but Sherpas have made the transition into a tourist economy: Men frequently gain employment as porters and guides, and women and men run private lodges along the main trekking routes (Ortner 1978, Jeffries and Clarbrough 1986).

Much of the land area within Sagarmatha is situated above the 3650 $\mathrm{m}$ tree line, and the fuel requirements of the resident population and increasing numbers of foreign tourists have placed great strains on the existing forests. It has been estimated that four times as much fuel wood is needed to cook a meal for a Western tourist than for a Nepali due largely to differences in diet (Tuting \& Dixit, 1986). The rising affluence of the Sherpas themselves have also placed strains on the mountain environment. As is the custom with many ethnic groups in Nepal, acquired wealth on a Sherpa family is generally placed into additional livestock, which lead to degradation of high mountain pastures in the vicinity of villages. This 
JOEL T. HEINEN AND BIJAYA KATTEL

newly acquired wealth and the fact that many people run lodges also increased the demand for timber in the park because people are building larger dwellings. Tourism in Sagarmatha, therefore, has had many direct and indirect environmental consequences(Jeffries, 1984; McNeely, 1985).

Several projects have been designed to improve the environmental situation in Sagarmatha and the lives of its resident Sherpas. The Himalayan Trust, begun by Sir Edmund Hillary, has sponsored several school, hospital, and bridge construction projects, and has also bought all the goats in the park and had them removed because they are more destructive than the more traditional yaks (Jeffries \& Clarbrough, 1986). The Government of New Zealand was instrumental in establishing the park and making physical facilities, and has been developing nurseries and plantations to increase the supply of fuel and timber. Several alternative energy projects such as improved cook stoves, solar water heaters, and a mini-hydroelectric generator have been completed under the auspices of HMG, the Government of New Zealand, and UNESCO's World Heritage Trust (Coburn, $1982 ; 1985$ ).

Many important religious sites are found in Sagarmatha including the monasteries at Tengboche and Thame. Nunneries are located in Devoche and Thamo, and other symbols of Buddhism such as prayer stones, prayer flags, and small shrines dot the landscape. Important wildlife in Sagarmatha include Himalayan tahr and black bear, musk deer, red panda, wolves (Canis lupus), and wild dogs. Snow leopards (Panthera uncia) may occur in the park, but there are no recent sightings. Wild yak (Bos grunniens) may occur in regions of Tibet bordering the park, and their domestic counterparts are common within. About 120 species of birds have been recorded in Sagarmatha.

Recent surveys suggest that populations of both Himalayan tahr and musk deer have increased substantially since the area has been protected. Musk deer are still occasionally poached in the park despite the protection offered by military guards. Kattel (1987) and Kattel and AlIdredge (1991) recently carried out an ecological study on musk deer in the park: the first such study to successfully tranquilize and radio-collar the animals. As is the case with other Himalayan protected areas, much more research is needed in Sagarmatha on the status of many wildlife species.

\section{Language National Park}

Langtang was recognized as an important protected area by Caughly (1969) during a preliminary survey. The park was created in 1976 and is $1,710 \mathrm{sq} \mathrm{km}$ in area, making it Nepal's third largest protected area; it also has the distinction of including the greatest amount of ele- 
vational range within its boundaries of any protected area in the country. The lower slopes, as low as $450 \mathrm{~m}$, are dominated by subtropical sal forests, and several peaks are over $7900 \mathrm{~m}$ tall. Approximately $25 \%$ of the area is forested, and slightly over $30 \%$ is under permanent ice and snow; the rest is composed mainly of alpine grass and scrub (Borradaile et al, 1977). Langtang is also important for tourism; over 5,000 trekking permits were issued for the area in 1986 (HMG, 1987b).

Over 3,000 people live within the park, and close to 17,000 may actually depend on the area for some resources, the latter being those living in villages surrounding the boundary, mostly to the south (Borradaile et al, 1977). There is great ethnic diversity within this region; traditional Hindu castes (Brahmin, Chhetri, etc.) are well represented as are several groups of Buddhist origin such as Tamang, Sherpas and Tibetans. Important religious sites within the peak include the monasteries at Sing Gompa and Kyanjin, and the sacred lake at Gosaikund situated at $4350 \mathrm{~m}$ in elevation, which attracts thousands of Hindu pilgrims during the festival of Shiva Ratri in the month of August. HMG operates two cheese factories in Langtang; they were the topic of the recent environmental impact assessment (Carter, 1987) due to the localized deforestation effects and disturbance on wildlife especially the endangered red panda (Yonzon \& Hunter, 1991).

Two government-run lodges are located in the park, and many private lodges are found along the trekking trail up Langtang Valley. Langtang is the only Himalayan park with road access from Kathmandu to the headquarters at Dunche, which houses the office, a small visitors' center, and the army.

Although Langtang is considered to be a Himalayan park, a full complement of Middle Hills flora and fauna is also found within its boundaries. Major wildlife species include leopard, musk deer, Himalayan tahr and black bear, wild dog, red panda, barking deer, goral, serow (Capricornis sumatraensis), wild boar, and several hundred species of birds. The endangered snow leopard and clouded leopard (Neofelis nebulosa) were also recorded in the original survey (Borradaile et al, 1977), but there are no recent sightings of either; the former may occasionally cross over one of the high passes from Tibet. Shrestha (1981) states that wild yak and great Tibetan sheep are also found in Langtang, but there are no verified records, though both are known to occur in areas just north of the border.

Like Sagarmatha, Langtang is zoned to exclude village areas from the park, and provide facility areas for local residents for grazing and fuel wood. Timber may also be cut by local residents on a permit basis. Five 
strict nature reserves, the only ones existing in Nepal, have been declared inside of Langtang; all are in inaccessible areas. Very little research has occurred to date within Langtang. A study on the endangered red panda was completed under the auspices of KMTNC and the World Wildlife Fund (WWF-US; Yonzon \& Hunter, 1991), and concluded that panda are threatened by various human activities in the park; especially problematic are the effects of domestic grazing animals on habitat, and wood cutting for the operation of the cheese factories. Despite protection by soldiers, some musk deer poaching reportedly occurs in Langtang.

\section{Annapurna Conservation Area}

The Annapurna region, located in the Western Development Region is probably one of the most important areas for tourist trekking in the world. The region contains the major peaks of Annapurna I, II, III, and IV, Annapurna South, the Nilgiri Himalayas, Tilicho, Lamjung, and Machapuchre. Circling this mountain system is a $320 \mathrm{~km}$ trekking route that passes through six districts in Nepal; over 33,000 trekking permits have been issued annually in recent years (HMG, 1987b). The trekking route passes along the south side of the Himalaya in one of the highest rainfall areas in Nepal, and along the north side in a high altitude desert. With this climatic diversity comes a great deal of cultural and biotic diversity as well. The Annapurna Circuit includes areas dominated by traditional Hindu castes (Brahmin, Chhetri, etc.), Gurung, Magar, Thakali, Tibetan, and Manangi ethnic groups and ranges from $450 \mathrm{~m}$ in elevation at its lowest point to $5400 \mathrm{~m}$ in elevation at Torung $\mathrm{La}$, its highest point. Many of the peaks located within the circuit are over $7600 \mathrm{~m}$ in elevation. Muktinath, situated at $3650 \mathrm{~m}$ on the northwest part of the region, is sacred to both Hindus and Buddhists.

The region has been proposed as a Recreation Area (Sakya, 1982), a national park (Bunting \& Wright, 1985), and the plan under implementation is a Conservation Area (Sherpa et al, 1986; Rana, 1989), approximately corresponding to IUCN Category $V$ (IUCN, 1990). The entire area, which includes $3,400 \mathrm{sq} \mathrm{km}$, is zoned into the following categories: wilderness zone, special management zone, protected forest, seasonal grazing zone, intensive use zone, and biotic/anthropological zone.

Although Langtang and Sagarmatha National Parks are effectively zoned, the proposal for Annapurna is unique in several respects. The proposal calls for maximum participation and management of the area by local people (Hough \& Sherpa, 1989), and it is estimated that, unlike existing parks in Nepal, revenues from tourism will completely support man- 
agement activities. User fees for tourists were proposed at NRs 200. The Annapurna Conservation Area Project (ACAP) called for a two-phase management scheme: Phase l, under implementation since 1987, concentrated on $800 \mathrm{sq} \mathrm{km}$ area south of the Annapura range, which has the highest human use, Phase II, begun in 1990, extended the area by $2,600 \mathrm{sq} \mathrm{km}$ and includes the area within the entire Annapurna Circuit. The headquarters is in Gandruk, Kasi District: a two-day walk northwest of Pokhara. A visitor's center is being built in Pokhara, and wildlife surveys of the northern part of the area have been completed.

Due to environmental degradation and the condition of the 40,000 human inhabitants in the region, ACAP is an integrated project and concentrates on five different areas: forestry and wildlife (both basic research and reforestation/nursery work), alternative energy development, community health (health, family planning, etc.), conservation education (including programs for local school and extension work), and tourism. This is a unique management scheme, and its success or failure could be used as a model in other developing nations (Hough \& Sherpa, 1989). The project has received support for WWF-US and KMTNC, as well as several smaller $\mathrm{NGO}^{\prime}$ s. N. Jain (personal communication) is currently doing an evaluation of ACAP.

\section{Dhor Patan Hunting Reserve}

Dhor Patan is $1,325 \mathrm{sq} \mathrm{km}$ in area and is the only hunting reserve in Nepal. The area was initially surveyed by Wegge (1976a), and the reserve was established in 1984. The headquarters is located in Dhor Patan, a largely Tibetan and Gurung community situated in Baglung District in the Western Development Region of Nepal. The reserve extends into Rukum District in the Midwestern Development Region. Dhor Patan can be reached in approximately four days on foot from Tansen, which is located along the Pokhara to Bairahawa Road. Dhor Patan Valley is situated at $2850 \mathrm{~m}$ in elevation; the reserve extends up to elevations in excess of $5500 \mathrm{~m}$ along the south slopes of the Daulagiri Himalaya. A STOL airstrip is located in Dhor Patan Valley, which is used to bring in parties of big game hunters by helicopter. The reserve is most famous for blue sheep (Pseudois nayaur) hunting although goral, serow, Himalayan tahr, barking deer, and wild boar are also hunted. Ecology and demography of blue sheep were studied by Upreti (1977).

The reserve is operated on a block system and contains a total of 7 blocks: five of these are registered to one licensed hunter and two are registered to another. The two guides specialize in blue sheep hunting and have mostly a foreign cliental. No more than 20 licenses may be 
issued for the entire area in any one year and hunters are subject to quotas on individual animal species as well.

One problem with the regulations to date is that the DNPWC field staff in Dhor Patan do not check bag limits (N. Mishra, pers. comm., former warden, Dhor Patan Hunting Reserve); the licensing is conducted at the main office of DNPWC in Kathmandu, and, after a party is done hunting, the guide fills in a standard form indicating how many of each species were harvested. This system has been effective so far, but it is potentially subject to abuse. It is unlikely that any large game populations are currently over-exploited in Dhor Patan, however, and some could probably tolerate heavier hunting pressures. The full complement of 20 licenses was issued for only one year in the five-year period from 1982 to 1987 (N.Mishra, pers. comm.). The total number of animals hunted for the winter 1986, 1987 season, as indicated by returned forms, was: 10 blue sheep, 5 serow, 12 Himalayan tahr, 8 goral, 1 barking deer, and 1 wild boar. Leopard and black bear may also be hunted, but these species are generally not pursued by licensed guides because the success rate of their harvest is very low. Hunters must purchase a general license, and separate complementary licenses for each of the first four species listed above.

Aside from large game species, other species recorded in the survey by Wegge (1976a) included lynx (Felis lynx), red panda, musk deer, and snow leopard. Wolves may also be transient in the area.

Wild dogs (Cuon alpinus), recorded as occasional by Wegge (1976a), are now reported for killing many head of livestock in Dhor Patan Valley. Residents also report some crop damage from wild boar. There is some poaching in the area, although its extent is not known. Local people frequently cut vertical sections out of the trunks of conifer trees to use as torches, resulting in the deaths of many trees. The biggest management problem in the reserve is grazing by domestic stock. Every year, generally from June to October, and estimated 80,000 head of livestock are brought from neighboring regions to graze in the high pastures above Dhor Patan (N. Mishra. pers. comm.); the grazing is completely uncontrolled to date.

As is the case in many other protected areas in the Himalayas, local residents may collect dry wood for fuel and may cut timber for their own use with permission. Hindu pilgrims visit the area during August, and Buddhist prayer flags and prayer stones dot the valley. Tourists visit the area in low numbers.

\section{Rara National Park}

Rara, created in 1976, is the smallest protected area in Nepal: $106 \mathrm{sq} \mathrm{km}$ in all. The park can be reached in a two to three day walk 
from Jumla, which has regular air service from Kathmandu and Nepalgunj. The park is important for its scenery, and it contains Lake Rara, which, at $10 \mathrm{sq} \mathrm{km}$ in area, is Nepal's largest lake. The lake is situated at $3050 \mathrm{~m}$ in elevation, and the park extends to elevations over $3950 \mathrm{~m}$.

Two villages, with a total population of 650 people, were previously located in Rara. This was considered inconsistent with the goals of the park (Bolton, 1976b), and the residents were moved out and relocated in Bardia District in the Terai, where many of them later died (Furer-Haimendorf, 1986). HMG has resisted suggestions to move residents out of Sagarmatha because of this tragedy. The people were mostly of the Thakuri ethnic group, and were descended from the royal court in Jumla, which fled to Rara with the advances of the Gorkha King into Jumla over 200 years ago. Remnants of the Thakuri villages still stand in Rara.

Mammals recorded in the park include leopard, black bear, wild dog, musk deer, goral and serow. Red panda may also occur in Rara (Bolton, 1976b). The larger predators are probably only transient in the area due to its small size. Many species of waterfowl visit the lake during spring and fall migrations. The vegetation includes high elevational forests of spruce, blue pine (Pinus excelsa), juniper, oaks, maples, Rhododendron, and bamboo. Areas above $3650 \mathrm{~m}$ are dominated by low scrub and alpine meadows. A government guest house is available for visitors, but few tourists visit Rara.

\section{Shey Phoksundo National Park}

Shey Phoksundo, 3555sq km in area, was established in 1984, and is Nepal's largest protected area. It is located in Dolpa and Mugu Districts in the Midwestern development Region of the country. The headquarters is located near Phoksundo Lake, about a two-day walk from the village of Shey, one of the field sites used by Schaller (1977) in his classic Himalayan wildlife study. The park is bordered on the south by the Daulagiri Hlmalaya, and is located within the trans-Himalayan region of the country. Due to rain shadow effect of the high peaks, it is physiographically more similar to the Tibetan Plateau, a cold, high altitude desert (Sakya, 1978; Schaller, 1977).

The region is sparsely populated by ethnic groups of Tibetan origin; several important Buddhist religious sites are located within the park: there are monasteries at Shey, Yangir, and Samling, as well as Shey Mountain, sacred to Dolpa Buddhists. People in the area rely on some agriculture as well as long distance trade with areas to the south; salt and wool are 
JOEL T. HEINEN AND BIJAYA KATTEL

brought down in exchange for food products. Dolpa produces only about half of its food needs, and, partly because of this as well as historical political disputes, most of the region was restricted until 1989, and could not be entered by foreigners.

Important wildlife in the area include blue sheep, Himalayan tahr, black bear, goral, serow, leopard, wolf, must deer, wild dog, wild boar, and snow leopard. The blue sheep which live in the vicinity of Shey are very tame because of the protection given by the presence of the monastery (Schaller 1977). The western side of the park was used as a the field site for Jackson and Ahlborn's (1986) study of snow leopard (also see Hillard 1989). This was the first long-term field study on the species, and was successful in radio-collaring and following five different animals, some for almost three years. Prior to that time, all that was known about these animals came from incidental and sometimes biased observations (summarized by Schaller, 1977).

Shey Phoksundo also contains habitat for many other species characteristic of the Tibetan Plateau, including wild yak, great Tibetan sheep, wild ass (Equus hemionus kiang), and Tibetan antelope (Pantholops hodgsoni). The presence of these species has not been confirmed in recent years, but much of the area has not been explored. Populations of these animals are found in Tibet north of Sino-Nepalese border. Brown bear (Ursus arctos) are listed by DNPWC, but their presence seems unlikely, at least as permanent residents (Schaller, 1977). Because of the known and possible presence of many rare species, as well as more common species, Shey Phoksundo is an extremely important protected area. There were formerly only two existing reserves, totalling $144 \mathrm{sq} \mathrm{km}$ in area, in the Tibetan Biogeographical Province in the People's Republic of China (IUCN, 1990), though another has been recently created (Anonymous, 1990). Although Shey Phoksundo is considered in the Himalayan Highland Biogeographic Province in the IUCN listing, its fauna has many Tibetan affinities. General wildlife surveys are urgently needed in Shey Phoksundo; a preliminary one was recently completed by Yonzon (personal communication), but Jackson and Ahlborn (1986) were not successful in obtaining permission to carry out a broad regional survey in the area due to its restricted status at the time.

\section{Proposed Hunting Reserves of Nepal}

Five hunting reserves in addition to Dhor Patan were proposed in the 1970 's and 1980's, but were not created for various reasons; they were originally proposed as part of the FAO/UNDP/HMG National Parks and Wildlife Conservation Project from 1973 to 1979 (UNDP, 
POPULATION AND ENVIRONMENT

1980). These hunting reserves were all planned in proximity to existing parks or wildlife reserves so that surplus animals could be harvested without jeopardizing the populations within the other reserves.

The proposed Rasuwa Hunting Reserve, located in the upper Trisuli Valley near the western boundary of Langtang National Park, was originally surveyed by Caughly (1969) in conjunction with the FAO/UNDP sponsored Trisuli Watershed Development Project. This area, along with Dhor Patan, was later surveyed by Wegge (1976a). The area proposed in Rasuwa ranges in elevation from 1700 to $5200 \mathrm{~m}$ and supports a wide variety of flora and fauna. Seven game mammals were recorded in Wegge's survey: goral, leopard, black bear, tahr, serow, barking deer, and wild boar. The endangered musk deer was also recorded and evidence for the presence of snow leopard was found. Wegge (1976a) recommended hunting quotas and fees for each large game species; he also pointed out, however, that the animals in this area are not particularly huntable for several reasons. They are either nocturnal (serow, boar, and barking deer), very sparely distributed (leopard and bear), or live in inaccessible areas (tahr). Goral, the only remaining species, is not a popular game animal. The most popular trophy species in the Nepal Himalaya is blue sheep, common in Dhor Patan but absent in Rasuwa. All districts containing national parks and wildlife reserves were later declared closed to hunting, and Rasuwa Hunting Reserve was never established for these reasons.

Four hunting reserves were proposed in the Terai at that time, and surveys and management plans were described by Wegge (1976b). The most eastern of these is Trijuga. The area initially proposed as a hunting reserve is $100 \mathrm{sq} \mathrm{km}$ in area, situated on the banks of the Trijuga River northwest of Kosi Tappu Wildlife Reserve. Wegge suggested that the reserve be divided into 10 different blocks, five located on the north side and five on the south side of the Trijuga River, a small tributary of the Sapt Kosi River. Wegge (1976b) proposed tentative quotas for sambar (Cervus unicolor), spotted deer, wild boar, blue bull, serow, leopard, sloth bear, and game birds (e.g. peafowl [Pavo cristatus], jungle fowl [Gallus gallus]). A $455 \mathrm{sq} \mathrm{km}$ area in Trijuga was proposed as a wildlife reserve in 1988 (B.N. Upreti, Director General, DNPWC, personal communication), but no action has been taken.

A second Terai hunting reserve was proposed in Bara District in the Central Development Region of Nepal. The area was to be divided into six blocks in three different groups of two blocks each, for a total area of $280 \mathrm{sq} \mathrm{km}$. Two of these blocks are located just east of Parsa Wildlife Reserve; the other four blocks are all located points further east. Wegge (1976b) gave quotas for spotted deer, barking deer, wild boar, sambar, sloth bear, and game birds, and he suggested that no hunting should be permitted for nilgai, leopard, and peafowl in the area due to their scarcity. This area was again surveyed by Sharma (1982) who suggested that 
JOEL T. HEINEN AND BIJAYA KATTEL

about $350 \mathrm{sq} \mathrm{km}$ of land should be incorporated into the reserve, and discussed many problems such as over-grazing and poaching in the region.

Hunting is legal in this and other forested areas outside of parks and reserves by Nepali nationals; however, the practice is virtually never legally scrutinized, and thus effectively unregulated in these areas. Sharma (1982) concluded that poaching and habitat destruction by grazing livestock contributed more to the decline of wildlife populations than inadequately controlled legal hunting.

Wegge (1976b) proposed two additional hunting reserves in the Terai: Banke (560sq km) and Bardia (320sq km). Both are located in the Terai of the Midwestern Development Region close to Bardia National Park. Eight blocks for Banke and six for Bardia were proposed. Tentative quotas were given for spotted deer, sambar, barking deer, wild boar, nilgai, sloth bear, leopard, and game birds for both reserves.

\section{A Note on Tourism in Protected Areas}

Some relevant information about tourism in the existing and proposed protected areas in Nepal has been included above; this section explores some other more general information about tourism in Nepal and some costs and benefits of tourism in protected areas. Many of the statistics reported here come from HMG (1987b) unless otherwise noted.

Since 1962, the time for which records have been kept, tourist arrivals to Nepal have increased greatly. A total of 6,179 entries were recorded in 1962 , which increased to 223,331 entries in 1986 . The gross foreign exchange earned from tourism rose for $\$$ US 78,000 to $\$$ US 42.9 million in the same time period. Between 1985 and 1986, the number of tourists to Nepal increased by $23 \%$ and foreign exchange by $19 \%$. Tourism is by far Nepal's largest industry, and it has been for quite some time. The largest single source of tourists to Nepal has been and continues to be Indian nationals. A total of 55,000 (or $38 \%$ of the total number of arrivals) was recorded for 1986, and this only included those who arrive by air because Indian nationals who arrive by land are not required to report at border checks, unlike all other people. Most Indian nationals come to Nepal for business purposes, or to visit the famous religious sites in Kathmandu, Lumbini, and Janakpur; they therefore comprise only a small percentage of tourists visiting protected areas.

The next largest tourist market to Nepal is from Western Europe, including all EEC countries, and Switzerland, Sweden, and Austria, followed by North America (USA and Canada), followed by Australia and the Pa- 
POPULATION AND ENVIRONMENT

cific. Among these individual countries, the largest percentage of tourists come from the USA (about 10\% of the total). Among the regions, however, Western Europe is by far the most important; $38 \%$ of all tourists to Nepal in 1986 were citizens of Western Europe. These industrialized nations are the most important for our arguments (below) for several reasons: They represent the great majority of tourists into Nepal's protected areas, and it is their currencies which are earning most foreign exchange for the country. Furthermore, people from these countries pose particular resource management considerations (see below); for example, Tuting and Dixit (1986) stated that per capita fuel wood consumption for foreign tourists is about four times that of Nepali nationals, due to differences in diet.

\section{DISCUSSION}

\section{Conservation of Biodiversity}

Conservation in Nepal proceeded at a very rapid pace since the enactment of the 1973 National Parks and Wildlife Conservation Act. Much of the earlier emphasis was on preservation of important species and areas, and the evidence suggests that HMG and its foreign donors have been largely successful in this goal (Upreti, 1991). For example, DNPWC records and recent research cited earlier show that many large mammal populations have increased: e.g., tigers, rhinos and ungulates in Chitwan, wild buffalo in Kosi Tappu, swamp deer in Bardia and Sukla Phanta, musk deer and tahr in the Himalayan parks, etc. Nepal now has 13 protected areas, and another imminent, covering over $10 \%$ of the country's land area, and incorporating areas from the lowlands to the highest peaks.

In addition to the existing and proposed protected areas discussed here, there is what amounts to a system of de facto nature reserves throughout Nepal: the many natural areas sacred to either Hindus or Buddhists in which human impacts are very small due to religious restriction (Jackson et al., 1990). Many such sites also exist within current protected areas, and some were discussed. In addition, many other areas, generally less than one to a few hectares in size, are found throughout the country, as are some larger areas such as Rani Ban, a forest on the rim of Kathmandu Valley which is protected by the Royal Palace. We know of no attempts to survey these sites for their distribution across the landscape, total area, or the biodiversity within them. Although small, some may prove to be very important for protecting rare plants and providing nesting habitat for many birds and denning sites for many mammals which may use a much larger area when active. Much more work is needed through- 
out Nepal to document the status and distribution of many species and their habitats (Heinen \& Yonzon, in prep).

The proposed hunting reserves in the Terai also contain habitat for several endangered species such as tiger, gaur, and elephant. Political realities were such that none of the reserves was established; the Forest Department still controls most of the land area within them and hunting by Nepali nationals occurs in all these areas to some degree. The rapid immigration to the Terai beginning in the early $60^{\prime} \mathrm{s}$ as a result of malaria eradication program (Gurung, 1983; Shrestha, 1981; Bista, 1991) was partly responsible. Furthermore, since the complete ban on tiger and elephant hunting has taken effect, it is doubtful that hunting reserves in the Terai would attract foreign big game hunters: the major market for blue sheep in Dhor Patan. There have been several proposals to use part of the proposed Bara Hunting Reserve for greatly needed agroforestry projects and as a source of fuel wood. Sharma (1982) objected to the latter use as he estimated that the area could not support the sustained removal of fuel wood as proposed by the Forest Department. At any rate, demand for fuel and timber have grown in Nepal, as has demand for arable land; for these reasons, the proposed Terai hunting reserves never materialized.

Since these proposals, much more land in the Terai has come under the control of DNPWC. Both Chitwan and Bardia were extended, and Parsa Wildlife Reserve was created as an additional extension to Chitwan since Wegge's (1976b) report. There have been more recent proposals to extend both Kosi Tappu and Sukla Phanta Wildlife Reserves, though no action has been taken. Adding to existing protected areas has therefore proven to be much more feasibly than creating new ones in the Nepalese Terai.

There have been suggestions that the current and proposed protected areas may be unable to preserve some aspects of biodiversity in the country. Heinen (1988) and Inskipp (1989), for example, suggested that the Kosi Barrage area south of Kosi Tappu Wildlife Reserve should be completely protected due to its importance for avian conservation. Inskipp (1989) also recommended protection for several wooded areas in the hills of Nepal that have a high avian diversity, particularly in the east. Although several of the existing Himalayan parks are large by Asian standards, most have substantial portions of their land cover in permanent ice and snow (e.g. $30 \%$ of Langtang, Borradaile et al 1977); the management zones in which some grazing and wood collection are permitted in several Himalayan parks mean that the effectively conserved area is substantially smaller than the map area. Clearly, human needs must be accounted for, and there is a trade-off between them and conservation; the future of some particularly 
POPULATION AND ENVIRONMENT

sensitive species which apparently cannot tolerate human disturbance is of concern (e.g., red panda; Yonzon \& Hunter 1991), and park management will by necessity become more involved with human management in Nepal.

\section{Management of Tourism in Parks and Protected Areas of Nepal}

The many successes within the current protected area system discussed above could not have been achieved without political and institutional will within HMG and the major influx of foreign aid in this sector. Part of the impetus leading to the inputs into conservation programs is due to tourism: Nepal's largest industry. Annapurna Conservation Area and Chitwan, Langtang, and Sagarmatha National parks are very popular attractions for foreign tourists (HMG, 1987a and b). There is a great potential for foreign tourism in other reserves as well (e.g., Bardia, Khaptad, and Rara National Parks). Tourism provides the single largest source of foreign exchange for the country's development plans and the largest source of employment besides agriculture for Nepali nationals. Tourism is the major source of income for residents of Sagarmatha, and is also an important source for residents of Annapurna, Chitwan and Langtang. Some aspects of tourism, however, represent costs (Bhattarai, 1985). The influx of tourists in great numbers into rural areas tends to reduce supply and increase demand for products, thereby increasing the prices that local people must pay (Mishra, 1984; Sherpa, 1985; Richter, 1989). Sherpa et al (1986) pointed out that the people who run lodges around the Annapurna Circuit, and therefore profit the most from tourism, are from traditionally well-off families who own large land-holdings. Although tourism is frequently advantageous in providing alternative incomes for people living in the vicinity of protected areas, there is frequently a conflict of national versus local interests in planning and assessing the costs and benefits of tourism (Whelan, 1991).

How the various costs and benefits are distributed becomes very important in the sustainability of tourism in protected areas (Sherman \& Dixon, 1991). Some ways to distribute the incomes from tourism more equitably at the local level include rural development schemes in areas most affected by tourism. This is the plan envisioned in the Annapurna Conservation Area Project (ACAP) and in the Makalu-Barun Project, and it has been carried out with mixed success in Sagarmatha with projects sponsored by HMG, the Himalayan Trust, UNESCO, and the Government of New Zealand. It should be pointed out that the situation in Sagarmatha may be fundamentally different than in other protected areas influenced by 
tourism (Chitwan, Langtang, and Annapurna) because most residents of Sagarmatha are of one ethnic group (Sherpas) with a very strong cultural identity. Rural development schemes involving local participation may be complicated by ethnic tensions in other, more ethnically mixed areas. In the case of Sagarmatha, Sherpas themselves have formed citizens groups that direct development projects in the park (Jeffries, 1984). The process may not run as smoothly elsewhere. The success of ACAP in involving local people of many different ethnic groups could be a very valuable model for other parts of the country because most areas in Nepal are ethnically mixed and some tensions between different ethnic groups are common.

Roberts and Johnson (1985) described how one mountain tourism operation attempted to distribute tourism revenues more equitably by expanding employment opportunities and providing markets for locallygrown foods. Several suggestions have been made toward similar ends around Chitwan National Park in conjunction with KMTNC, including agroforestry and nursery programs (E. Dinerstein, personal communication, WWF-US). KMTNC also sponsored the building of a nursery at the headquarters of Kosi Tappu to supply fuel and fodder trees to local residents. A total of 5,000 seedlings were distributed during the first year of operation (1987; G.R. Singh, former warden, Kosi Tappu Wildlife Reserve, personal communication). These projects, integrated with the management of protected areas, will hopefully produce the dual benefits of improving living conditions of local people and improving their attitudes about the protected areas, thereby decreasing the park/people conflicts which affect most Nepalese protected areas. This is an integral problem of park management in Nepal (Lucas \& Bajimaya, 1987).

Despite some successes made in regard to meeting needs of local people and tourists in protected areas in Nepal, there are many more needs to be met. For example, there are no current training or development schemes for Langtang National Park like those described for Annapurna and Sagarmatha, despite that Langtang is a popular destination for tourists. Furthermore, there is currently little coordination between the Central Immigration Office and the DNPWC to inform tourists about the protected status and legal requirements for entering mountain parks. For example, the former park admission fee (NRs 60) was identical to the trekking permit fee, giving many tourists the mistaken impression that they were paying twice for the same thing, leading to complaints (N.W. Sherpa, Warden, Sagarmatha National Park). This could have been completely avoided if tourists were given park brochures, available free of charge from DNPWC, at the immigration office when they purchased their trekking permits. An- 
other complaint frequently heard from tourists in mountain parks is the lack of sanitary facilities; Sagarmatha is acquiring somewhat of a reputation in these regards (Mishra, 1986). Obviously, tourists themselves cause these problems, but it is up to park authorities to alleviate them. The ACAP has addressed this problem in its management plan.

As previously mentioned, foreign tourists use up to four times the amount of fire wood per person per meal as do Nepali nationals. This, coupled with the fact that many high elevational forests are already overexploited at a time when tourist entries are increasing, has led to the tree planting and alternative energy schemes for Sagarmatha and Annapurna (Coburn, 1985; Sherpa et al., 1986). There are no similar schemes for Langtang, and those in existence for Sagarmatha may be inadequate given the growing pressures. Nepal's population is expected to grow to anywhere from 21 to 26 million by the turn of the century (HMG, 1991; both high and low projections based on 1980 census figures), and the number of tourists entering the country is projected to approach one million by the same year. Much more action is obviously needed to conserve remnant forests if these projections hold true. Expeditions and large trekking parties in the Himalayan parks are required to be self-sufficient (HMG, 1980), and kerosene depots are located in Sagarmatha and Annapurna as well. If more extreme measures are not taken, however, the government's desire to increase tourism at such a rapid rate could ironically produce to the opposite effect, for the majority of western tourists come to see the Kingdom's fabled natural beauty, which is rapidly succumbing to the double burden of rapid population growth and increasing numbers of tourists.

Visitors centers are also needed in Nepal's protected areas. Attractive and informative centers are now found in Chitwan, Sagarmatha, and one has been built recently for the Annapurna Conservation Area. A small display, recently upgraded, is also found in Langtang. Visitor's centers should also be planned for Nepal's other protected areas because they could be used in conservation-education schemes aimed at local residents, as well as at army staff posted in protected areas, most of whom currently receive no special training for DNPWC duty. The general need for expanded conservation/education has been discussed by Panday 1985). This need is recognized by both DNPWC and KMTNC, and conservation education was one of the priorities of the second $\mathrm{HMG} / \mathrm{FAO} / \mathrm{UNDP}$ National Parks Project.

All of Nepal's protected areas sponsor an annual meeting between elected local leaders and park authorities. His Majesty the King has recently proclaimed that all parks and reserves are to sponsor an additional meeting several times per year between the ranking DNPWC officer and 
other HMG officials within the region including the Chief District Officer and District Police Chief in addition to the meeting with local village leaders (G.R. Singh, former warden, Kosi Tappu Wildlife Reserve, personal communication). Attractively displayed visitor's centers could be useful in educating these local and district leaders about benefits provided by protected areas, and such facilities could, of course, be visited by local school groups. The potential benefits of having a visitor's center aimed at school groups in Shivapuri due to its proximity to the dense population center of Kathmandu Valley were already discussed. Visitor's centers can and should be used to educate tourists and local residents alike. One strategy under longterm consideration would be to staff each protected area with a conservation education person to coordinate programs at all levels within the districts that contain protected areas.

\section{Employee Training Considerations}

Along with tourists come special needs and specially trained people to deal with them. One of the stated goals of ACAP was to educate lodge owners about sanitation and food preparation (Sherpa et al., 1986). Heinen (1990) discussed a training program for local, nonprofessional tour guides in Chitwan based in recommendations by U.R. Sharma, former Chief Warden, Royal Chitwan National Park. The course was designed to improve English and crosscultural skills and provide some factual information about natural history and the history and management of the park. Graduates of the training later unionized to improve their working conditions.

Overseas training programs have been sponsored by the Government of New Zealand for several residents of Sagarmatha. The successful applicants were educated in park management and have returned to their own district to manage this reserve. ACAP has also sent several local residents from the Annapurna region to New Zealand for the same purpose. Several advantages can be pointed out with regard to this policy. These people are the most knowledgeable about local culture, customs, and language, and should, therefore, be able to incorporate attitudes of residents into management practices than would managers from other regions. Since they are themselves local, their positions as officers in protected areas may help to convince local people that the reserve is, at least in part, for their benefit, and this would hopefully lead to better overall public relations than would be the case if outsiders of different ethnic groups from different parts of Nepal were to assume the post.

There are several disadvantages to this practice as well. Regions that 
POPULATION AND ENVIRONMENT

contain protected areas are, for the most part, remote and the quality of education within them is not as good, which means that local applicants may not be as well qualified as people from other areas. Furthermore, law enforcement could become a problem if an officer's own relatives, friends, or acquaintances were involved in any illegal activities. For this reason, the DNPWC has had a long-standing policy of rotating wardens fairly regularly. Finally, and most important to date, some hostilities can develop when employees with more tenure are not give similar opportunities and are surpassed in rank by newcomers sent on special programs for no other reason than their district of residence and ethnic group. Any benefits accrued by a decrease in park/people conflicts must be weighed against this cost. Other overseas trainings were sponsored by the 1973 to $1979 \mathrm{FAO} /$ UNDP National Parks Project (UNDP, 1980), and many of the current wardens and other senior officers in DNPWC were sent to study for graduate degrees. Lucas and Bajimaya (1987) expressed the opinion that using foreign aid to send employees on study leave for long periods should be reconsidered because of the shortages it creates, and because people in managerial posts do not need advanced research degrees; such aid could be used elsewhere. However, we contend that there is one major advantage to this practice: it improves morale and provides incentives for wellqualified and experienced professionals to stay in DNPWC and not transfer to other departments within the Ministry of Forests and Soil Conservation.

In addition to protection staff of DNPWC, army personnel are posted within most of the protected areas of Nepal. They have been effective in offering more protection to these areas, but there are problems as well; the military protection units currently absorb up to $70 \%$ of the DNPWC budget, which imposes monetary constraints on the department (Lucas \& Bajimaya, 1987). Furthermore, the trend of conservation legislation in the country has moved from strict protection to allowing more human uses. Thus, the role of the army in Nepali protected areas is in need of review and possibly reconsideration. Annapurna Conservation Area, which has no army personnel, may be a test for the appropriateness of using soldiers as protection staff in Nepal's protected areas (Heinen \& Kattel, in prep).

\section{CONCLUSIONS}

As Nepal faces the next century, population pressures on the country's protected areas will mount from the duality of the population growth rate of the country itself, and from tourism. In addition, the rising aspirations of the Nepalese people will further the burdens on natural areas (Shah, 
JOEL T. HEINEN AND BIJAYA KATTEL

1988). The main management problems faced by the DNPWC in its varied reserves result from park/people conflicts. Innovative ways must be developed to provide direct incentives for local people living near reserves to lessen these conflicts and enhance conservation strategies (McNeely, 1988). There is an ever increasing need to expand education and citizen participation programs in the context of protected area management, and there is a great need to provide alternatives to local people for products they now obtain from protected areas. It is likely that the removal of some forest products is sustainable (e.g., thatch grass removal from the Terai reserves; Lehmkuhl et al, 1988; Heinen in press b), but it is also likely that the removal of other forest products is not (e.g., fuel wood from Himalayan reserves; Miller \& Tangley, 1991). There are several programs in place to provide energy alternatives for organized trekking groups, but it is evident that these will not suffice, and some high mountain areas are already feeling the pressures.

In addition, there is a great need to develop nation-wide biological inventory and monitoring programs. There is precious little information on the distributions and abundances of virtually all species except for some of the large endangered vertebrates, and the natural diversity of most taxa is very high in Nepal for two reasons: The great geographic diversity, and the fact that the country forms part of the border of two biogeographic realms (the Palearctic and the Indo-Malayan), and has elements from both. A recent UNDP/FAO project addressed this (Bauer \& Timmerman, 1987), but monitoring has been sporadic in time and space; trained manpower and economic resources for sustaining these efforts are lacking. More detailed nation-wide inventories of natural forests outside of protected areas would enhance this endeavor, especially for the de facto reserves which are comparatively well protected because they are sacred; we feel that these areas have been completely ignored as repositories of biodiversity, and they may provide important habitat for many species.

\section{REFERENCES}

Anonymous. (1985). Makalu-Barun nature conservation seminar. Kathmandu: KMTNC/ Woodlands Mountain Institute.

Anonymous. (1990). The Makalu-Barun National Park and Conservation Area management plan. Kathmandu: DNPWC/Woodlands Mountain Institute.

Bauer, J.J. (1990). Status and population trends of swamp deer (Cervus d. duvauceli) in Bardia Wildlife Reserve, Nepal. Tiger Paper XVII(3): 16-19.

Bauer, J.J. \& Timmerman, C. (1987). Natural resource inventory implementation program, Chitwan National Park. Kathmandu: UNDP/FAO Working Document No. 1. 
POPULATION AND ENVIRONMENT

Bell, D.J. (1987). A study of the biology and conservation of the hispid hare. Unpubl. Report. Univ. of East Anglia, School of Biological Sciences.

Bezruchka, S. (1985). A Guide to trekking in Nepal. Fourth Edition. Kathmandu: Sahayogi Press.

Bhattarai, S. (1985). Environmental impact of tourism on mountain ecosystems. In Anonymous (Ed.). People and protected areas in the Hindu Kush Himalaya (pp 49-54). Kathmandu: KMTNC/ICIMOD.

Bista, D.B. (1991). Fatalism and development: Nepal's struggle for modernization. Calcutta: Orient Longman.

Blower, J.H. (1971). Proposed national park in Khumbu District. Kathmandu: Unpubl. Report to the Secretary of Forests.

Bolton, M. (1975). Royal Chitwan National Park management plan. Rome: FAO/UNDP. National Parks and Wildlife Conservation Project, Nepal. Working Document No. 2.

Bolton, M. (1976a). Royal Karnali Wildlife Reserve management plan. Rome: FAO/UNDP. National Parks and Wildlife Conservation Project, Nepal. Working Document No. 6.

Bolton, M. (1976b). Lake Rara National Park management plan. Rome: FAO/UNDP. National Parks and Wildlife Conservation Project, Nepal. Working Document No. 3.

Borradaile, L., Greene, M., Moon, L., Robinson, P. \& Tait, A. (1977). Langtang National Park Management Plan. Rome: FAO/UNDP. National Parks and Wildlife Conservation Project-Nepal. Working Document No. 7.

Bunting, B.W. \& Wright, R.M. (1985). Annapurna National Park. In Anonymous (Ed.). People and protected areas in the Hindu Kush Himalaya (pp 63-70). Kathmandu: KMTNC/IClMOD.

Bustard, H.R. (1982). Crocodile breeding project . In V.B. Saharia (Ed.). Wildlife in India (pp 147-163). Dehra Dun: Natraj Publishers.

Byrne, P. (1990). Tula Hatti: The last great elephant. Boston: Faber and Faber.

Carson, B. (1985). Erosion and sedimentation processes in the Nepalese Himalaya. Kathmandu: ICIMOD Occasional Paper No. 1.

Carter 1. (1987). Organizations concerned with forestry in Nepal. Kathmandu: ICIMOD Occasional Paper No. 3.

Caughly, G. (1969). Wildlife and recreation in the Trisuli Watershed. Kathmandu: Trisuli Watershed Develop. Project Report No. 6.

Coburn, B. (1982). Alternative energy sources for Sagarmatha National park. Parks, 7(1), 16-18.

Coburn, B. (1985). Energy alternatives for Sagarmatha National Park. In Anonymous (Ed.). People and protected areas in the HIndu Kush Himalaya (pp 71-72). Kathmandu: KMTNC/ICIMOD.

Dahmer, T. (1978). Status of wild Asian buffalo in Nepal. Unpubl. MS Thesis, University of Montana.

Dhungel, S. (1985). Ecology of the hog deer in Royal Chitwan National Park. Unpubl. PhD Dissertation. Univ. Montana.

Dhungel, S., Brawner, C., \& Yoder, J. (1990). Elephant training and management in Nepal. Tiger Paper, (Bangkok) XVII(4), 1-6.

Dinerstein, E. (1979a). An ecological survey of Royal Karnali-Bardia Wildlife Reserve, Nepal. Part 1. Vegetation, modifying factors and successional relationships. Biological Conservation, $15,127-150$.

Dinerstein, E. (1979b). An ecological survey of Royal Karnali-Bardia Wildlife Reserve, Nepal. Part 2. Habitat/animal interactions. Biological Conservation, 16, 265-300.

Dinerstein, E. (1980). An ecological survey of Royal Karnali-Bardia Wildlife Reserve, Nepal. Part 3. Ungulate populations. Biological Conservation, 18, 3-37.

Dinerstein, E. \& McCracken, G.F. (1990). Endangered greater one-horned rhinoceros carry high levels of genetic variation. Conservation Biology, 4(4), 417-422.

Eckholm, E.P. (1976). Losing ground: Environmental stress and world food production. New York: W.W. Norton and Co. 
JOEL T. HEINEN AND BIJAYA KATTEL

Edds, D.R.(1988). The fishes of Royal Chitwan National Park. Journal of the Natural History Museum (Kathmandu), 10, 1-12.

Evans, M., Heardman, C., Houghton, S. \& Tiler, C. (1985). An ecological survey of the Narayani River. Unpubl. Report to the DNPWC, Kathmandu.

Fleming, R.L., Sr., Fleming, R.L., Jr., \& Bangdel, L.S. (1984). Birds of Nepal (third edition). Kathmandu: Nature Himalayas. Avalok Publishers.

Furer-Haimendorf, C. von. (1986). Foreword: Development with a human face. In L. Tuting \& P. Dixit (Eds.). Bikas/Binas: Development and Destruction (pp 11-14). Munich: Goebuch.

Gurung, K.K. (1983). Heart of the jungle. London: Andre Deutsch Ltd.

Halliday, J.B. (1982). A study of the ecological distribution of birds along the Rapti and Narayani Rivers in Chitwan National Park. Unpubl. Report to DNPWC. Kathmandu.

Heinen, J.T. (1987). Interim report for the Kosi Tappu wild buffalo/human interaction project. Unpubl. Report to DNPWC, Kathmandu.

Heinen, J.T. (1988). Rare and new bird records for Kosi Barrge and Kosi Tappu Wildlife Reserve, Nepal. During Winter and Spring, 1987. Journal of the Natural History Museum (Kathmandu), 10(1-4), 23-30.

Heinen, I.T. (1990). The design and implementation of a training program for tour guides in Royal Chitwan National Park, Nepal. Tiger Paper, XVII(2), 11-15.

Heinen, J.T. (in press a). A population viability analysis for wild buffalo in Kosi Tappu Wildlife Reserve, Nepal. Biological Conservation.

Heinen, J.T. (in press b). Park-people relations in Kosi Tappu Wildlife Reserve, Nepal: A socio-economic analysis. Environmental Conservation.

Heinen, J.T. \& Thapa, B.B. (1988). A feasibility study of a proposed trekking tail in Royal Chitwan National Park. Journal of the Forestry Institute (Kathmandu) 10, 19-28.

Heinen, J.T. \& Kattel, B. in prep. The evolution of conservation law in Nepal. $30 \mathrm{pp}$. ms.

Heinen, J.T. \& Yonzon, P.B. in prep. A review of the status of target species in Nepal: Priorities for biodiversity conservation.

Hillard, D. (1989). Vanishing tracks: Four years among the snow leopards of Nepal. New York: Arbor House.

HMG. (1977). National Park and Wildlife Conservation Act 2029 (1973). Kathmandu: Ministry of Law and Justice.

HMG. (1980). The Himalayan National Parks Regulation. Kathmandu: Ministry of Law and Justice.

HMG. (1982). King Mahendra Trust for Nature Conservation Act. Kathmandu: Ministry of Law and Justice. Nepal Gazette, 34(26).

HMG. (1987a). Statistical yearbook of Nepal. Kathmandu: National Planning Commission. Central Bureau of Statistics.

HMG. (1987b). Nepal tourist statistics, 1986. Kathmandu: Ministry of Tourism.

HMG (1991). Statistical yearbook of Nepal. Kathmandu: National Planning Commission. Central Bureau of Statistics.

Hough, J.L. \& Sherpa, M.N. (1989). Bottom up versus basic needs: Integrated conservation and development in the Annapurna and Michiru Mountain Conservation Areas in Nepal and Malawi. Ambio, 19(8), 434-441.

Inskipp, C. (1989). Nepal's forest birds: Their status and conservation. Cambridge, U.K.: International Council for Bird Preservation Monograph No. 4.

Inskipp, C. \& Inskipp, T. (1985). A Guide to the birds of Nepal. London: Croom Helm Ltd.

IUCN. (1984a). An Introduction to the world conservation strategy. Gland, Switzerland: IUCN Publications.

IUCN. (1984b). National conservation strategies. Gland, Switzerland: IUCN Publications.

IUCN. (1986). United Nations list of national parks and protected areas 1985. Gland, Switzerland: IUCN Publications.

IUCN. (1990). 1990 United Nations list of national parks and protected areas. Gland, Switzerland and Cambridge, UK.: IUCN Publications. 
POPULATION AND ENVIRONMENT

Jackson, R. \& Alborn, G. (1986). Himalayan snow leopard project, Final progress report. Unpubl. Report to the National Geographic Society.

Jackson, R. \& Alborn, G., H.S. Nepali, \& Sherpa, A.R. (1990). Aspects of wildlife protection and utilization in the Makalu-Barun Conservation Area. Kathmandu: DNPWC/ Woodlands Mountain Institute Report 11.

Jeffries, B.E. (1984). The Sherpas of Sagarmatha. In J. McNeely \& K.R. Miller (Eds.). National parks, conservation, and development. Washington, D.C: Smithsonian Institution Press.

Jeffries, M. \& Clarbrough, M. (1986). The story of Mt. Everest National Park. Auckland: Cobb/ Horwood Publications.

Joshi, S.C. (Ed.). (1986). Nepal Himalaya: Geo-ecological perspective. Nani Tal, India: Himalayan Research Group.

Kattel, B. (1987). The Himalayan musk deer ecology project. Unpubl. Annual Report to DNPWC, Kathmandu.

Kattel, B. \& Alldredge, A.W. (1991). Capturing and handling of the Himalayan musk deer. Wildl. Soc. Bull, 19(4), 397-399.

Laurie, A. (1978). Behavior and ecology of the greater one-horned rhinoceros. Unpubl. PhD Dissertation. Cambridge University.

Lehmkuhl, J.F., Upreti, R.K. \& Sharma, U.R. (1988). National parks and local development: Grass and people in Royal Chitwan National Park, Nepal. Environmental Conservation, 15(2), 143-148.

Lucas, P.H.C. \& Bajimaya, S.S. (1987). National parks and wildlife development plan. Kathmandu: National Plan for Forestry Sector. Unpubl. Report to HMG.

Majapuria, T.C. (Ed.). (1981). Wild is beautiful. Madya Pradesh, India: S. Devi.

Majapuria, T.C. (Ed.). (1984). Nepal- Nature's paradise. Bangkok: White Lotus.

Mali, T.N. \& Shah, S. (1987). Preliminary report on Makalu-Barun Nature Reserve. Unpubl. Report to DNPWC, Kathmandu.

Maskey, T.M. (1982). Progress report on the Charial Project in Nepal. Unpubl. Report to DNPWC, Kathmandu.

Maskey, T.M. (1984). Survey of Gharials in the Kosi, Narayani, and Kali Gandaki Rivers. Unpubl. Report to DNPWC, Kathmandu.

McDougal, C. (1980). The face of the tiger. London: Andre Deutsch, Ltd.

McNeely, J.A. (1985). Man and nature in the Himalayas. In Anonymous (Ed.). People and protected areas in the Hindu-Kush Himalayas (pp 25-30). Kathmandu: KMTNC/ICIMOD.

McNeely, J.A. (1988). Economics and biological diversity: Developing incentives for conserving biological resources. Gland, Switzerland: IUCN Publications.

Miller, F.R. \& Tangley, L.(1991). Trees of life: Saving tropical forests and their biological wealth. Boston: Beacon Press.

Milton, J. \& Binney, G. (1980). Ecological planning in the Nepalese Terai. Washington, D.C: Threshold Publishers.

Mishra, H.R. (1981). Ecological studies on the prey species of tiger. In T.C. Majapuria (Ed.). Wild is beautiful (pp 408-416). Madya Pradesh, India: S. Devi.

Mishra, H.R. (1982). Ecology of cheetal in Royal Chitwan National Park, Nepal, with comparison with the hog deer, sambar, and barking deer. Unpubl. PhD Dissertation. Univ. Edinbugh.

Mishra, H.R. (1984). A Delicate Balance: Tigers, rhinoceros, tourists and park management vs. the needs of local people in Royal Chitwan National Park. In J. McNeely \& K.R. Miller (Eds.). National parks, conservation, and development (pp 197-205). Washington, D.C: Smithsonian Institution Press.

Mishra, H.R. (1986). Deforestation and environmental degradation through tourism in Nepal. In L. Tuting \& K. Dixit (Eds.). Bikas/Binas: Development and Destruction (pp 320-324). Munich: Geobuch.

Ortner, S. (1978). Sherpas through their rituals. New Delhi: Vikas Publications.

Panday, S.B. (1985). Natural resource conservation education in Nepal. Unpubl. Diploma Thesis. Lincoln College, New Zealand. 
JOEL T. HEINEN AND BIJAYA KATTEL

Rana, D.A. (Ed.). (1989). Annapurna Conservation Area Project: Three year retrospective progress Report. March 1986-December 1989. Kathmandu: KMTNC.

Richter, L.K. (1989). The politics of tourism in Asia. Honolulu: University of Hawaii Press.

Roberts, J.O.M. \& Johnson, B.D.C. (1985). Adventure tourism and sustainable development . In Anonymous (Ed.). People and protected areas in the Hindu-Kush Himalaya (pp 81-84). Kathmandu: KMTNC/ICIMOD.

Sakya, K. (1978). Dolpa: The world behind the Himalayas. Kathmandu: Jore Ganesh Press.

Sakya, K. (1982). Annapurna National Recreation Area. Unpubl. Report to DNPWC, Kathmandu.

Santiapillai, C. \& Jackson P. (1990). The Asian elephant: An action plan for its conservation. Cambridge, U.K.: IUCN Publications.

Schaaf, C.D. (1978). Population size and structure and habitat relations of barasingha in Sukla Phanta Wildlife Reserve, Nepal. Unpubl. PhD Thesis. Michigan State University.

Schaller, G.B. (1977)., Mountain monarches. Chicago: Univ. Chicago Press.

Shah, S. (1988). Nepal's economic development: Problems and prospects. Asian Survey, 28(9), 945-957.

Sharma, U.R. (1982). Proposal for the creation of Bara Hunting Reserve. Kathmandu: Unpubl. Report to DNPWC.

Sherman, P.B. \& Dixon, J.A. (1991). The economics of nature tourism: Determining if it pays. In T. Whelan (Ed.). Nature Tourism (pp 75-88). Washington, D.C: Island Press.

Sherpa, L.N. (1985). Management issues in Nepal's national parks. In Anonymous (Ed.). People and protected areas in the Hindu Kush Himalaya (pp123-126). Kathmandu: KMTNCI ICIMOD.

Sherpa, M.N., Coburn, B. \& Gurung, C.P. (1986). Annapurna Conservation Area, Nepal: Operational Plan. Kathmandu: Unpubl. Report to KMTNC.

Shrestha, T.K. (1981). Wildlife of Nepal. Kathmandu: Curriculum Development Center. Tribhuvan University Press.

Smith, J.L.D. (1980). The dispersal pattern among tigers. Unpubl. PhD Dissertation. Univ. Minnesota.

Stainton, J.D.A. (1972). Forests of Nepal. London: John Murray and Co.

Storrs, A. \& I. Storrs. (1984). Discovering trees in Nepal and the Himalaya. Kathmandu: Sahayogi Press.

Tamang, K.M. (1979). Population characteristics of the tiger and its prey. Unpubl. Report to DNPWC, Kathmandu.

Taylor-Ide, D. (1985). The Barun Valley report. Unpubl. Report to DNPWC, Kathmandu.

Taylor-Ide \& Shrestha, T.B. The Makalu-Barun Park: A Proposal. In Anonymous (Ed.). People and protected areas in the Hindu-Kush Himalaya (pp 129-132). Kathmandu: KMTNC/ ICIMOD.

Thorsell, J. (1985). World heritage report-1984. Parks, 10(1), 8-9.

Tuting, L. \& Dixit K. (Eds.). (1986). Bikas/Binas: Development and destruction. Munich: Geobuch.

UNDP. (1973). National parks and wildlife conservation-Nepal. Rome: Unpubl. UNDP/FAO Project Document.

UNDP. (1980). National parks and wildlife conservation-Nepal. Project findings. Rome: Unpubl. UNDP/FAO Project Document.

Upreti, B.N. (1977). Population ecology of blue sheep and management considerations. Unpubl. MS Thesis. Michigan State University.

Upreti, B.N. (1985). The park/people interface in Nepal: Problems and new directions. In Anonymous (Ed.). People and protected areas in the Hindu-Kush Himalayas (pp 19-24). Kathmandu: KMTNC/ICIMOD.

Upreti, B.N. (1991). Status of national parks and protected areas in Nepal. Tiger Paper, $X V I I I(2), 27-32$.

Wegge, P. (1976a). Himalayan Shikar Reserves. Rome: FAO/UNDP National Parks and Wildlife Conservation-Nepal. Document No. 5. 
POPULATION AND ENVIRONMENT

Wegge, P. (1976b). Terai Shikar Reserves. Rome: FAO/UNDP National Parks and Wildlife Conservation-Nepal. Document No. 4.

Whelan, T. (1991). Ecotourism and its role in sustainable development. In T. Whelan (Ed.). Nature tourism (pp 3-22). Washington, D.C: Island Press.

Yonzon, P.B. \& Hunter, M.L. Jr. (1991). Cheese, tourists, and red panda in the Nepal Himalayas. Conservation Biology, 5(2), 196-202. 